\title{
Oral Tradition and Legal Authority in the Trans-Mountain Acequia Systems of the Mora Valley, New Mexico
}

\author{
Enrique R. Lamadrid ${ }^{1} \&$ Juan Estevan Arellano ${ }^{2}$ \\ ${ }^{1}$ University of New Mexico, Albuquerque, NM, USA ${ }^{2}$ Acequia Junta y Ciénaga, Embudo, NM, USA \\ lamadrid@unm.edu, estevanarellano@gmail.com
}

\begin{abstract}
During the 18th century conflicts between the Comanches of the southern Plains and the Spanish Mexicans and their Pueblo allies in New Mexico, the valley of Mora was a natural corridor to the settlements of the Río Grande valley for trade and warfare. The walls of Picurís Pueblo on the other side of Jicarilla mountain sheltered native Tiwas as well as their neighbors. When peace came, mestizo settlers headed east to Mora to begin farming and ranching. The land was fertile, but water was scarce, since it naturally flowed west to the Río Grande. As early as 1817, settler José Antonio Olguín approached the elders of Picurís where he had lived for years, for permission to divert some water from one of the Tres Ritos del Río Pueblo over the mountain to the other side. Since then the controversies and competition for water have grown over the years. With adjudication of water rights of Mora approaching, what is the valueof oral history in legal proceedings? How would it be possible to consult living voices to create a legally recognizable source of information? Several examples of this oral and documentary process illustrate the case of the trans-mountain "waterfall acequias" of Mora, including an inconclusive 1882 legal case filed by Picurís Pueblo, declarations of pueblo leaders, local interviews, and a 2008 children's book, Juan the Bear and the Water of Life by the authors of this article. Although there is little possibility for any of these testimonies to complement future legal proceedings, it is important to understand cultural processes of historical validation where the documentary record is so sparse.
\end{abstract}

Keywords: oral tradition, adjudication of water rights, trans-mountain acequias, Mora and Picurís, New Mexico

"Los valles de Mora son verdes más por su cultura que por su naturaleza..."

"The valleys of Mora are green more for their culture than for their nature..." Antonio Medina (2007)

"...para su sorpresa dijeron los ancianos de Picurís que sípodian desviar el agua de poniente hacia oriente si hallaban el modo de hacerlo. Posiblemente los tiwas consintieron porque pensaban que dicha tarea de ingeniería sería imposible."

"...to their surprise the elders agreed to allow them to divert water from the west to the east if they could find a way. Perhaps the Tiwas consented because they thought that such feat of engineering was impossible.

Estevan Arellano (2008)

\section{Introduction: story, history, and legend: recuerdos, permisos, promesas}

In 2008, Juan Estevan Arellano collaborated with Enrique R. Lamadrid, to write a children's book entitled Juan the Bear and the Water of Life / La acequia de Juan del Oso. As prologue, with parents in mind, he inscribed the following compilation of multi-source oral and written narratives he grew up about the settlement of the Mora Valley, across the mountains from 
his home village of Embudo, New Mexico. At the heart of the story is the creation of three prodigious water sources, the famous "waterfall acequias" of Mora. Components of this foundational story are enacted in performance all across the region on a daily basis as part of an oral tradition worthy of dissemination beyond the valley and beyond a children's book, which is the motivation to present it now to a scholarly audience.

With an ethnographic ear and the cultural authority of an elder, Arellano evokes both the spirit and the orality of the story, complete with dialogic components, and the authorizing elements of genealogy and topography (Briggs 1988). He inscribes both oral history, drawn from events witnessed during his lifetime, and oral tradition, those "accounts of past events that were handed down in traditional form to the narrator (Briggs 1987: 242)."Within the "moral economy" of water (Rodríguez 2006: 75-80), the key ethical element for Mora, is the permiso, the oral permission of the elders of Picurís Pueblo for their allies and relatives to divert water from the middle fork of the Rio del Pueblo to settle and farm the other side of Jicarita mountain in 1817.

\subsection{Mora valley acequias in indo-hispano oral tradition - Arellano narrative}

The acequias of the upper Mora Valley are the highest and most famous traditional irrigation systems in New Mexico. Almost in defiance of gravity, they elevate water from three westflowing forks of the Rio Pueblo in the Sangre de Cristo Mountains, up and over a high mountain ridge, across a sub-continental divide and to the east, from the vast watershed of the Rio Grande to the immense watershed of the Mora, Canadian, Arkansas, and Mississippi Rivers. The men, women, and children that accomplished this feat belong as much to history as to legend, and this is their story.

It is said that when some adventurous souls decided to cross La Jicarita, Gourd Mountain to the lands beyond, they just picked up and left. They knew that on the other side lay a verdant valley which led east to the buffalo plains where great herds of cibolos roamed. In fact it was the ciboleros who had traversed the valley on their treks to the llano estacado to hunt the buffalo. With a growing population, lands were becoming scarce on the western slopes of the Sierra Madre, known much later as the Sangre de Cristos after the railroad came. And since youth has always been adventurous, young men challenged each other, "vámonos pa'l otro lado de la sierra," let's go to the other side of the mountain. "There's plenty of land and water where we can raise our families without want." They were following the tradition of their ancestors, who left the silver mining town of Zacatecas in 1596 in search of a new land.

And so from one day to the next, a group assembled, packed up and headed across the divide. They all knew the area; they were all ciboleros, a breed of tough norteños who knew how to survive. They packed their horses and mules; it was an early April day and all you could hear was, "vámonos, vamos," amidst all the dust stirred up by horses and mules ready for the trip. Se despidieron, they said good-bye to their parents, their queridas, and asked for their blessing from their grandparents. They all knelt to be blessed, les echaron la bendicion and they took off. On their way they led the cattle to their summer pastures, to Tres Ritos and El Cañon de la Junta. They would be back in the late fall with wagon loads of jerky and hides, or maybe earlier in August to stock up on chileverde and the other vegetables and fruits they craved.

"It was a group of about twenty men, all in their late teens and twenties, all of them tough as rawhide, garrudos and corriosos. They were from Embudo and Picurís, others from Trampas, Santa Bárbara and some from as far as Santa Cruz de la Cañada and la Soledad del Río 
Arriba, all related somehow to each other and the Martín Serrano clan, the family of the first land grant in the Española Valley.

The first families crossed over the mountains in 1816, then again in 1835, under the Spanish then Mexican flags, although not much had really changed since the time of the Viceroys of New Spain. Here the people did what they had to do to survive and they could care less under which banners they lived. The Nuevo Mexicanos were independent and proud, hard workers who labored from sunup to sundown as was their custom.

But after opening up the land on the other side of the mountain, after carving the landscape with acequias and contra-acequias like a living sculpture and bringing their first crops in, they realized they would eventually need more water. After the young who had ventured across the sierra grew old enough to watch their grand children work the land, they realized they had to make serious plans for future generations. Hoping and praying for more rain and snow was not enough. They had to secure a more generous flow of the precious liquid to nourish the valley. They got together and decided to bring water from the other side of the mountain. They agreed they could not just go and take it. As men of honor and respect, they realized they should ask permission from the elders of Picurís Pueblo, on the banks of the Río Pueblo. The Tiwas had settled first and were the keepers of the water. By that time, many Nuevo Mexicanos had grandfathers and grandmothers in Picurís. They were mestizos and would never single-handedly do anything to harm their neighbors and relations. A group of men from El Trampero and El Rito Negro (today Chacón), led by José Antonio Olguín (born in 1769 and married in San Lorenzo de Picurís en 1791), made the trek across the Jicarita from where they originally came to talk to their parientes, about the possibility of getting more water for their crops and growing population.

On the west side of La Jicarita the development of irrigated agriculture had worked its way up from the mouth of the tributaries of the Río Grande like the Rio Santa Cruz and Rio Embudo. On the other side it worked its way from the top down. The elders of Picurís needed to discuss and consider the request. But even if they agreed for the water to be shared, how would such a monumental task be achieved? On their way back home, some went on horseback to visit their primos and abuelitos for a few days then headed back across the sierra. About a year passed before they heard from Picurís, and to their surprise the elders agreed to allow them to divert water from the west to the east if they could find a way. Perhaps the Tiwas consented because they thought that such feat of engineering was impossible.

There were no easy solutions to achieve their goal. Besides their determination and the strength of their horses and oxen, their only technologies were wooden plows, ropes, pulleys, and a half filled brandy bottle to serve as a level. Almost nobody had shovels with metal blades in or 1835. How could the river be coaxed to flow in the opposite direction? Even today it would be a daunting project costing million of dollars not to mention the environmental challenges. But somehow, they made it happen. Historical documents and the maps of today bear the names of these people inscribed on canyons, springs, and mountains: Olguín, Martínez, Durán, Romero, Arellano, Abeyta, Lucero, Archuleta, Borrego, Cruz, Gonzales, Luján, Meléndez, Lara, Madrid, Suazo, Tapia, García, Medina, Trujillo, Valdez, Gallegos, Mascareñas, Gandert, Montaño, Martín, Ortega, Páez, Pacheco, Sánchez, Salazar, Vigil, among others. The three trans-mountain acequias are officially registered as: La Acequia del Rito Negro (c. 1825) La Acequia del Rito y la Sierra (1865), and La Acequia de la Sierra (1882). Many years have passed. Since only a few families have passed on 
stories with very much detail, legends and myths have set in" (Lamadrid and Arellano 2008: $4-9)$.

\section{Lo de Mora: historical, cultural, and economic contexts}

The relationship between communal memory and documentary history are complex and contentious (Vansina 1965). If oral history and tradition "are concerned with the meaning of those [past] events for the participants and the present generation," the semantic field of documents focuses on "the details with respect to the official (governmental or ecclesiastical) status of events" (Briggs 1987: 240). The narrative gleaned by historians from the documentary record is built upona fundamental bias for the hegemony of the written word, concern for "objectivity" and legal status (Arellano, 1985 and 1995, Ebright, 2005).

Originally developed for commerce in ancient times, writing was soon taken over by religion and the law. But the oral and written word follow the same "procedure whereby human action becomes institutionalized, authoritative, and recognized as canonical" (Goody, 1998, p.3). Similar principles of inclusion and exclusion apply for both. In the end, writing actually de-contextualizes the fluidity of the oral, whose relevance is closely tied to the evolution of a community.My summary of the history of Mora follows:

During the devastating wars of the second half of the 18th century between the Comanches, the Spanish Mexicans and their Pueblo allies in New Mexico, the valley of Mora east of Jicarilla peak and the canyons of the Río Pueblo to the west were a natural trading and raiding corridor between the Great Plains and the valley of the upper Río Grande. Occupied since the 8th century and recipient of a Merced or Land Grant from the Spanish Crown in 1689 the fortified pueblo of Picurís stood sentinel on the route, where the canyons broadened into a series of mountain valleys. For many decades, the thick adobe walls of Picurís sheltered native Tiwas as well as well as their new Spanish Mexican neighbors. By the mid 1700s, population growth in the central valley of the Río Grande had led to competition for resources. Despite the dangers, settlers ventured into the other great watersheds of the Pecos, Canadian, and San Juan, looking for suitable lands to farm and graze their herds.

When the warfare began to subside, mestizo settlers left Picurís and headed over the passes and east to Mora to found farms and ranches. The land was fertile, but water was in short supply, since most of it naturally flowed west to the Río Grande. Led by José Antonio Olguín, soon 75 families were clustered around a new town named San Antonio de lo de Mora at the head of the valley. In 1818, they petitioned for a priest to serve their spiritual needs. Over the next decade, weary from the rigors of frontier life and attacks of other native groups coming off the plains, most everyone moved back to the safety of Picurís. By 1832, according to accounts of American trappers the town was abandoned and in ruins, but the settlers returned in great enough numbers that they applied for and were awarded a Land Grant in 1835 by Mexican governor Albino Pérez (Arellano 1985). Some of the original grantees were plains Apache families driven off the plains by the Comanches.

Eleven years later, the U.S. invasion of New Mexico during the Mexican American War, produced inevitable conflict and resistance in Mora. After disputes with American traders in January 1847 erupted in violence, the most populous village in the Santa Gertrudis area of the lower valley was completely razed by American artillery in reprisal (Herrera 2000). But soon Mora became inextricably entwined with the commerce and new military installations of the U.S. New Mexico Territory. With its trans-mountain acequia systems, the valley 
quickly developed into of the most robust agricultural centers in New Mexico, which offered wheat and all kinds of produce to travelers on the nearby Cimarrón route of the Santa Fe Trail, and to Fort Union, the U.S. Army's largest military installation between Kansas and California between 1851 and 1891.

Demand for water resources in the Mora Valley led to the creation of two more transmountain acequias from the north fork of the Río Pueblo above the village of Chacón by 1865, and the south fork above the village Holman by 1882 (Arellano, 1995; Kryder, 2010). With a large fort to supply, water resources in the Mora valley took on strategic importance for the United States Army. Concerned with the further tapping of their Río del Pueblo, Picurís challenged the new acequias in an unsuccessful 1882 lawsuit (Case \#256, County of Taos). Interestingly enough, the first acequia of José Antonio Olguín (c.1825) was not mentioned, a tacit recognition of its orally based legitimacy (Kryder, 2010).

The arrival of the railroad in 1878 and the closing of the fort a few years later turned the wealthiest county in state into the poorest. But the modern economic paradigm of New Mexico was laid down in Mora - a service economy that maintains the huge regional military establishment.New Mexico is still a internal military colony of the United States.

The subsequent, century-long economic depression in Mora has largely preserved area from the over-development that blights the entire "Front Range" of the Rockies, from Fort Collins south to Pueblo. Mora is the first county in the nation which has passed an ordinance banning the process of hydraulic fracturing "fracking" in the search for energy, whose dire effects on subterranean water systems is not fully understood yet (Cart, 2013). Unlike the verdant mountain valleys to the north, the Mora Valley is not naturally green. It is "culturally green" and intricately crisscrossed by dozens of acequias.

\section{Acequia culture and water rights: costumbre, tradición y resistencia}

The origins and sources of Mora's ancestral acequia systems are still clouded in legend and mystery because clarification might possibly jeopardize them. In the context of oral tradition, it is important to remember that legend is not fiction, but a type of "belief narrative" in which the belief of the interlocutor is negotiated to lend credibility to the story (Briggs, 1988, p. 277). One of the reasons for the continuing uncertainty in Mora is community apprehension concerning the inevitable adjudication process to settle questions of ownership of water rights. Over the past century, watershed by watershed, the state of New Mexico has been slowly and carefully adjudicating water resources. Over allocation of water on paper already exceeds the actual water that exists on and below asemi-arid high desert landscape.

Before the Water Laws of 1907 separated water rights from land rights, water was always intimately joined to land. Documentary references to acequias are very scarce in the historical record. They appear mostly in relation to their proximity to other prominent features such as molinos or water driven mills, linderos or property boundaries, and milpas or agricultural fields. The same laws also established the Priority Doctrineto determine ownership of water rights. "First in time, first in right" designates senior users. In most areas of northern New Mexico, the doctrine privileges indigenous groups whose ancestral presence on the land predates the arrival of Spanish Mexican settlers. The immediate emergence of a mestizo population dating to Spanish colonial times further complicates the situation, since American law has difficulty 
in distinguishing ethnicity and membership in the indigenous polities it has attempted to define and rule.

\subsection{Adjudication of water rights in New Mexico}

The practice of adjudication is based on three inter-related elements to declare a water right for an acequia:

-The point of diversion and quantity of water consumed and acreage irrigated.

-The purpose of use, periods and places of use, land and ownership of land to which the water right is appurtenant.

-The establishment of a priority date (Kryder, 2010, p. 15).

Parciantes, the water users on acequia, often avoid full collaboration with the process, when there is contention or doubts. In recent years the acequias of Mora have resisted the attempts of the State Engineer to appoint Water Masters to oversee water use on acequias which have functioned successfully in times of drought and in times of plenty for over a century (García, 2008).

A key question is whether oral belief narratives delay or cloud the process. The community is aware of the hegemony of the word and the lack of documentation of water. The oral tradition which has lent authenticity to their claims and customs is excluded from legal proceedings. The case in point is that nobody is certain of the exact location of the 1825 acequia dug by José Antonio Olguín and the first settlers, since it no longer flows. The middle fork or rito of the Río Pueblo flows west from a veritable maze of canyons. Since the diversions sometimes followed natural watercourses, only a diligent archaeological survey could locate the course of the first trans-mountain acequia of the upper Mora valley. The continuing mystery of its location, and the reluctance to actually find it may actually enhance its legitimacy and moralauthority in the imagination of the people, if not in court. Unlike documentary history, oral history, is a social product controlled by the community. It is shaped by the community's "views of who can legitimately say what to whom in which circumstances... In short, oral history is power" (Briggs, 1987, p. 256, 259).

\subsection{Water sharing traditions: el repartimiento de las aguas}

Another important cornerstone of acequia culture is the ancient custom of repartimiento, the sharing of water during droughts (Rivera, 1998, p.164-172; Rodríguez, 2006, p. 57-58). Repartimiento is not codified, but specifically negotiated in relation to people and place. Two historic agreements on water sharing between Native and Non-native water users were negotiated in the Taos valley and the Río Jémez watershed, which was decided outside court (Rodríguez, 2006, p.35-74; NM Water Dialogue, 1996). Executive director of the New Mexico Acequia Association (NMAA) Paula García regularly delivers an eloquent oral summary of the working customto groups as diverse as farmers, students, and legislators:

Since every year was different, acequias had to learn how to share limited water in real time. They had to rely on generational memory and observation to estimate the flow of rivers and streams. And when Spring was upon them, they had to decide among themselves how to share the water as fairly and equitably as possible. After generation upon generation, these arrangements became the customs and traditions of the acequias. In many 
communities, these customs continue and are sometimes called the "reparto" or "repartimiento."

A custom is an agreement among people that is carried on by oral tradition, practice, or both. It depends on having a common set of values and a common understanding. Customs are not easily enforced by a higher authority; they depend on a level of agreement about a common need or resource. In the case of water sharing, customs are based on a shared belief in equity and mutual respect. Some examples of a water sharing custom are those that are practiced within acequias (García, 2014)."

As Briggs concludes, "The oral record's strength lies rather in interpreting the character of life in the past" (1987: 243), a central factor of the "moral economy of water." All of the major researchers of traditional water management in New Mexico, including Anselmo Arellano (1985, 1995), Stanley Crawford (1988, 2000), Leslie Kryder (2010), José Rivera (1998), and Sylvia Rodríguez (2006) rely on interviews as well as documents for their insights into acequia culture.

The ongoing "Mayordomo Project" conducted by the Alfonso Ortiz Center of the Maxwell Museum of Anthropology at the University of New Mexico is a major survey of practice and practical knowledge of the mayordomos, the elected stewards of the approximately one thousand acequia systems of New Mexico (NMAA 2008). The ongoing "Escuelita de las Acequias" workshops for mayordomos sponsored by the NMAA also depend on dialogue and shared praxis (Trujillo 2012).

\section{Indigenist essentialism vs. indo-hispano realities: mestizaje y alienación}

The doctrine of Priority Rights as it applies to water rights adjudication is ultimately predicated on legal definitions of indigeneity, how Native groups are defined and identified under the law. The ultimate decision regarding membership in federally recognized tribal entities was based on a US Supreme Court case 436 U.S. 49 (1978), Santa Clara Pueblo v. Martínez, which originated in New Mexico, and which reaffirmed tribal sovereignty and the right of tribal groups across the nation to determine their own membership (Stetson 1980). It also opened the door to a kind of exclusivist essentialism by which many tribes determine membership, especially since the advent of tribal casinos and dividing their spoils. A 2011 op-ed piece in the Taos News by then governor of Picurís Pueblo, Gerald Nailor underscores the implicit ambiguities of tribal membership and sovereignty in the northern Tiwa community of c. 324 members (BIA, 2014).

"My turn: Water a life-giving source for Picurís."

"During the late 1800s and early 1900s, there were some families who were Picurís People who lived in the Mora Valley East of the Picurís Peak.

"This area was considered Ancestral Territory of the Picurís. A herd of buffalo always came to a small lake surrounded by aspen at the base of the mountains.

"Since farming and livestock raising was new, some of the families turned to another way of sustenance. 
"Due to the lack of water, a Picuris person came to the Tribal Council to ask for permission to divert a small amount of water from one of the tributaries. Permission was granted. As years went by, the man passed on, and the Picurís approval was forgotten.

"The people moved back to Picurís as more people moved into the area. The diversion expanded and slowly crept up the mountain and over to the Western watersheds that feed the Río Santa Barbara and Río Pueblo and many more tributaries. These diversions have also expanded into the Western slopes of Chacón Canyon.

"Around in 1915 the Picurís became concerned about these first diversions and approached the state government. The Picurís delegation left the meeting with an understanding that the diversions will stop and the water flow naturally.

"Oral history tells us of a big rock in the middle of one of the main tributaries that naturally divided the flow — that rock was later blasted" (Nailor, 2011, emphasis mine).

According to the oral tradition of the settlers of the Mora valley, the very person who first asked for permission to divert the water was José Antonio Olguín. Did his years of residence in Picurís define his indigeneity for later generations? Perhaps, since in 1817, there was no legal designation distinguishing Natives from Non-natives. Despite the attempts of the Spanish government to separate and insulate Spanish Mexican and Pueblo Indian communities from each other to avoid conflicts, their very proximity led to the emergence of a mestizo majority of culturally Indo-Hispano people (Gutiérrez, 1991).

\subsection{Sacando la acequia del Rito Griego y la Sierra-Lamadrid narrative}

This discussion of oral tradition and legal authority in the case of the trans-mountain acequias of Mora concludes with an oral history drawn directly from the experience of the author of the present study:

The first week of June, 2010, I was invited along with a colleague and two friends from the Mora valley towns of Chacón and Ledoux, to participate in the annual cleaning or sacaof the Acequia del Rito Griego y la Sierra, which supplies the farms and pastures of Chacón, nine hundred feet below.We joined about a dozen peones or workers recruited for the task, armed with shovels and a chain saw. The mountain sunlight above 11,000 feet was intense and the meadows were full of wildflowers. But in the shadow of looming spruce and fir forests along the well maintained acequia, deep patches of snow still lingered. The main object of the day's work was shoveling out snowdrifts and removing fallen branches along a three mile section nearly horizontal stretch of the ditch before its almost vertical descent to the valley. The mayordomo paced the acequia and assigned stretches of about ten yards each to the peones. We began at a small lake above the timberline, which was tapped by a tiny rivulet which joined the headwaters of the upper fork of the Río del Pueblo just above the new concrete diversion dam, complete with baffles and ladders to separate the native cutthroat trout above from the population of hatchery rainbow trout below.

Conversations with the other workers ranged from summer plans, to recently planted gardens, and the annual task of taking livestock to their summer pastures in the forest. The peones were proud of the new dam, so many years in coming. Several older peones expressed some trepidation about the pending adjudication of the water rights of their acequia. As we worked, we also talked about the school year and family activities. 
As an educator, I of course asked more about school and where previous generations had been educated before the construction of Mora High School. Some had attended the local Presbyterian elementary school in Chacón and transferred to Allison James School in Santa Fe and Menaul School in Albuquerque.Surprisingly, a number of people from the pre and post war generations went away to Saint Catherine Indian School in Santa Fe. Many families still had ties to Picurís Pueblo or acknowledged ancestors from there. Although none were on pueblo rolls, the federal government recognized kinship ties close enough to be invited and admitted to attend Indian boarding schools.

Although casual conversation is anecdotal at best, as with many other communities of northern New Mexico, Indo-Hispano cultural roots in the Mora valley run deep (Lamadrid 2010).

At the heart of the struggle for water resources lies the challenge of defining cultural and historical Priority. In what he terms "hegemonic multi-culturalism," Thomas Guthrie discusses how politics of recognition and authenticity are negotiated in New Mexico in relation to the past.The presumption is that groups have "an essential cultural identity... and demonstrate 'authenticity' and cultural continuity through time" (2013: 9). The little herd of buffalo herd that returned yearly to the base of Picurís mountain serves as icon and metaphor of indigeneity and authenticity in Governor Nailor's story, which symbolically claims the contested waters for Picurís Pueblo. What is ultimately affirmed is the status-quo and state control of the commons and a deeper authorization and perpetuation of colonialism in a region twice colonized in the last four centuries. The interplay of document and oral narrative continue as Native and Indo-Hispano groups negotiate their future and the limited resource which both sustains and limits the growth of their communities and the equilibrium of their presence upon the land.

\section{Afterword - Juan del Oso: tribulations and triumphs of the bear's son}

As Enrique Lamadrid and Estevan Arellano searched for an Indo-Hispano metaphor of indigeneity and authenticity to convey the lessons of the history of acequias in the Mora valley to younger readers, the traditional stories of Juan del Oso came to mind. We followed legend into myth to carry the narrative. The son of a young woman and a bear, the character personified the heroism and resourcefulness of settlers in an arid mountain landscape.

The bear is an ancient symbol of both the power of nature and the benevolent animus that empowers human beings. The bear's son brings superhuman strengths to the monumental tasks facing his people to survive upon the land. Juan del Oso also follows the hero's path leading to alienation from his community, followed by reintegration into it, bearing the gifts he brings home from the wild side. Under the guidance of his father Oso Grande, he and his two youthful allies from the folk tales, Mudarrios (river mover) and Mudacerros (mountain mover) bring water over the top of the mountains to the people of Mora.

To achieve the necessaryand complementary equilibrium between myth and history, the actual historic participants in the heroic story are mentioned one by one with a list of surnames of the founding families of the valley. We intertwined history, legend, and myth to tell the story and inscribe its ethical heart, the permiso of the elders of Picurís. 


\section{Acknowledgments}

Ethnographic Field Schools on Acequia Culture in the Mora Valley in 2007 and 2008 were supported by grants from the Center for Regional Studies at the University of New Mexico. Collaborators include Harold and Lucille Trujillo from the New Mexico Acequia Association (NMAA), graduate and undergraduate students and our colleague, photographer Miguel Gandert. For information about current issues vital to the acequias, consult the website of the NMAA http://www.lasacequias.org.

\section{References}

Arellano, A.F. ([1985] 1994): Acequias de la Sierra and Early Agriculture of the Mora Valley. Guadalupita, NM: Center for Land Grant Studies.

Arellano, A.F. (c.1995): Agricultural Productivity in Mora County: 1880s-1890s: The End of the Century, the End of an Era. Unpublished paper, Las Vegas, NM.

Briggs, C.L. (1988): Competence in Performance: the Creativity of Tradition in Mexicano Verbal Art. Philadelphia: University of Pennsylvania Press.

Briggs, C.L. (1987): Getting Both Sides of the Story: Oral History in Land Grant Research and Litigation. In Charles L. Briggs and John R. Van Ness, eds. Land, Water, and Culture: New Perspectives on Hispanic Land Grants. Albuquerque: University of New Mexico Press, pp. 217168.

Bureau of Indian Affairs (2014): Pueblo of Picurís. www.bia.gov/WhoWeAre/ Regional Offices/ Southwest/What/index.htm (accessed May 20, 2014).

Cart, J. (2013): New Mexico County First in Nation to Ban Fracking to Safeguard Water.Los Angeles Times, May 28.

Crawford, S.G. (1988): Mayordomo: Chronicle of an Acequia in Northern New Mexico. Albuquerque: University of New Mexico Press.

Crawford, S.G. (2000): The Heart and Soul of an Acequia: A New Mexico Community Turns to the Past to Protect its Water.Land \& People. Santa Fe: Spring.

Ebright, M. (2005): Land Grant / Pueblo Histories.Guadalupita, NM: Center for Land Grant Studies.

García, P. (2008): Office of State Engineer Appoints Water Masters.Noticias de las Acequias. Santa Fe: New Mexico Acequia Association, November. http://archive.constantcontact.com/fs042/1101711440364/archive/1102318517167.html\# LETTER.BLOCK8 (accessed May 15, 2014).

García, P. (2014): Repartimiento: Water Sharing in Times of Drought.Santa Fe: New Mexico Acequia Association, June 6. http://www.lasacequias.org/news/repartimiento(accessed May 12, 2014). 
Goody, J. (1998): Canonization in Oral and Literate Cultures. In A. van der Kooij \& K. van der Toorn, eds. Canonization and decanonization. Lieden, Boston, Brill, pp. 3-16.

Guthrie, T.H. (2013):Recognizing Heritage: The Politics of Multiculturalism in New Mexico. Lincoln: University of Nebraska Press.

Gutiérrez, R.A. (1991):When Jesus Came The Corn Mothers Went Away: Marriage Sexuality And Power In New Mexico 1500-1846. Stanford, California: Stanford University Press.

Herrera, C.R. (2000): New Mexico Resistance to U.S. Occupation. In The Contested Homeland, A Chicano History of New Mexico, Albuquerque: University of New Mexico Press, pp. 23-42.

Kryder, L. (2010): The Trans-Basin Acequias of the Mora Valley, New Mexico. Unpublished paper, Albuquerque.

Lamadrid, E.R. (2010): Sacando la Acequia del Rito Griego y la Sierra. Field Notes, June.

Lamadrid, E.R. and J.E. Arellano (2008): Juan the Bear and the Water of Life: La Acequia de Juan del Oso. Illustrated by A.Córdova. Albuquerque: University of New Mexico Press.

Medina, A. (2007): Interview with UNM Field School on Acequia Culture. Chacón, NM, June.

Nailor, G., Governor of Picurís Pueblo (2011): My turn: Water a life-giving source for Picurís.Taos News, Thursday, July 28.

New Mexico Acequia Association (2008): Mayordomo Project. Santa Fe: NMAA. http://www.lasacequias.org/mayordomo-project/ (accessed May 20, 2014).

New Mexico Acequia Association (2006): El Agua es Vida. Declaración para El Congreso de las Acequias. Santa Fe: NMAA, 2006.

New Mexico Water Dialogue (2013): Healing the Jémez. Santa Fe: New Mexico Water Dialogue Newsletter, [November 1996] Fall. http://nmwaterdialogue.org/newsletter/dialogue-fall-2013 (accessed June 1, 2014).

Rivera, J.A. (1998): Acequia Culture. Albuquerque: University of New Mexico Press.

Rodríguez, S. (2006): Acequia: Water Sharing, Sanctity, and Place. Santa Fe: School for Advanced Research.

Stetson, C.L. (1980): Tribal Sovereignty: Santa Clara Pueblo v. Martinez: Tribal Sovereignty 146 Years Later. American Indian Law Review 8, 1: 139-159.

Trujillo, P. (2012): Escuelita de lasAcequias: Reflections on the Past Year. Santa Fe: NMAA. http://www.lasacequias.org/mayordomo-project/ (accessed June 1, 2014).

Vansina, J. (1965): Oral Tradition: A Study in Historical Methodology. H.M. Wright, trans. Chicago: Aldine Publishing Company. 